\title{
Industrialized cashew juices: variation of ascorbic acid and other physicochemical parameters
}

\author{
Sucos de caju industrializados: variação no teor de ácido ascórbico e em outros parâmetros físico-químicos
}

\author{
Christiane de Queiroz PEREIRA ${ }^{1}$, Flávia Conde LAVINAS ${ }^{1}$, \\ Maria Lúcia Mendes LOPES$^{1 *}$, Vera Lúcia VALENTE-MESQUITA ${ }^{1}$
}

\begin{abstract}
Commercial cashew apple juice is widely accepted in the Brazilian market. Cashew apple has high content of ascorbic acid, an important nutrient to human beings. Ascorbic acid content in food can be affected by processing and storage conditions. Commercial cashew apple juice samples, ready-to-drink and concentrated, were analyzed. The ascorbic acid content, total titratable acidity, total soluble solids, and $\mathrm{pH}$ of the juices were determined during storage at $4{ }^{\circ} \mathrm{C}$ after the containers were opened. The ascorbic acid content presented a great variability among the samples analyzed ranging from 37.3 to $46.3 \mathrm{mg} .100 \mathrm{~mL}^{-1}$ in ready-to-drink juices and from 75.7 to $152 \mathrm{mg} .100 \mathrm{~mL}$-1 in concentrated juices. The storage of commercial cashew apple juices for 48 hours at $4{ }^{\circ} \mathrm{C}$ resulted in ascorbic acid losses of up to $8.8 \%$ for concentrated and $6.4 \%$ for ready-to-drink juices. The other parameters remained stable during storage. The results of this study point to the importance of considering ascorbic acid losses in commercial cashew apple juices which occurs after opening but before the expiration date expires.
\end{abstract}

Keywords: fruit juice; cashew apple; storage; stability.

\section{Resumo}

Sucos de caju industrializados são amplamente aceitos no mercado brasileiro. O caju contém alto teor de ácido ascórbico, importante nutriente para o ser humano. O teor deste nutriente pode ser afetado pelo processamento e pelas condições de estocagem dos alimentos. Foram analisadas amostras de sucos industrializados de caju, prontos para o consumo e concentrados. O teor de ácido ascórbico, a acidez total titulável, o teor de sólidos solúveis totais e o $\mathrm{pH}$ dos sucos foram determinados durante estocagem a $4^{\circ} \mathrm{C}$, após abertura das embalagens. Houve grande variabilidade no teor de ácido ascórbico entre as amostras, 37,3 a $46,3 \mathrm{mg} .100 \mathrm{~mL}^{-1}$ nos sucos prontos para o consumo e 75,7 a $152 \mathrm{mg} .100 \mathrm{~mL}^{-1}$ nos sucos concentrados. A estocagem dos sucos por 48 horas a $4{ }^{\circ} \mathrm{C}$ resultou em redução do teor de ácido ascórbico em até $8,8 \%$ para os concentrados e em até $6,4 \%$ para os prontos para o consumo. Os demais parâmetros analisados permaneceram estáveis durante a estocagem. Os resultados deste estudo demonstram a importância de se considerar a redução do teor de ácido ascórbico que ocorre em sucos industrializados de caju durante o período de validade, após a abertura da embalagem.

Palavras-chave: suco de fruta; caju; estocagem; estabilidade.

\section{Introduction}

Consumer demand for safe, functional, and fresh products has been increasing continuously, which contributes to the increasing consumption of fruit juice and fruit juice-based drinks. These products are also appreciated due to their sensory properties and wide variety of taste and flavors (CAMPOS et al., 2002; KABASAKALIS; SIOPIDOU; MOSHATOU, 2000).

Cashew (Anacardium occidentale, L.) tree has a large socioeconomic importance to Brazilian Northeast (FALVELA, 2004; MAIA; MONTEIRO; GUIMARÃES, 2001). Its main product, the cashew nut, is widely appreciated and is the primary reason for its cultivation. The bottom portion of the cashew is a pseudo fruit called cashew apple, which has a pulpy and juicy composition. The most important cashew apple products are the commercial juices (concentrated or ready-to-drink), which are widely accepted in the Brazilian market (VALIM; ROUSEFF; LIN, 2003).
The cashew apple composition is very complex. If the presence of vitamins, tannins, minerals, organic acids, and carbohydrates makes it an important food, on the other hand, it makes the fruit highly perishable requiring special care with storage, transportation, cleaning, and processing (EUROPEAN PARLIAMENT AND COUNCIL DIRECTIVE, 2005; FDA, 1988). The cashew juice has high contents of ascorbic acid and phenolic compounds and their oxidation results in the development of off-flavor and browning.

The vitamin C content in a cashew apple is approximately five times higher than in an orange and it can be considered a good source of this nutrient (AKINWALE, 2000; CAVALCANTI, 1998; INYANG; ABAH, 1997). This nutrient is important to the absorption of iron, amino acid metabolism, hormones, and cell oxidoreduction processes (MARÍN et al., 2002). Processing and storage conditions applied for juice preservation have to be evaluated because they can significantly affect its vitamin C

Recebido para publicação em 29/10/2000

Aceito para publicação em 14/12/2000 (002962)

Departamento de Nutrição Básica e Experimental, Instituto de Nutrição, Universidade Federal do Rio de Janeiro - UFRJ, CEP 21941-590, Rio de Janeiro - RJ, Brasil,

E-mail:mlucia@nutricao.ufrj.br

${ }^{*}$ A quem a correspondência deve ser enviada 
contents (KABASAKALIS; SIOPIDOU; MOSHATOU, 2000; REDDY; LOVE, 1999).

Nutritional information is necessary to guide consumers who must know how to balance diets toward beverage intakes in order to get the maximum benefit from their vitamin $\mathrm{C}$ content (KABASAKALIS; SIOPIDOU; MOSHATOU, 2000; SOARES et al., 2004). There are many studies to determine the ascorbic acid (AA) content in fruit juices but only a few focus on determining the amount of AA lost in different fruit juices during storage (KABASAKALIS; SIOPIDOU; MOSHATOU, 2000; LAVINAS et al., 2003). No studies about AA stability in commercial cashew apple juice were found in the literature.

The purpose of this study was to evaluate Ascorbic Acid (AA), Total Soluble Solids (TSS), Total Titratable Acidity (TTA), and $\mathrm{pH}$ stability in commercial cashew juice samples, during storage under refrigeration $\left(4^{\circ} \mathrm{C}\right)$.

\section{Materials and methods}

\subsection{Samples}

Eleven samples of commercial cashew apple juices were collected in the city of Rio de Janeiro, RJ, Brazil before the expiration date expires. The products consisted of 3 brands of Ready-to-Drink Juice (RDJ) and 8 brands of Concentrated Juice (CJ) that were numbered 1-11. For each product, three lots were analyzed. All samples were kept at $4{ }^{\circ} \mathrm{C}$ for 48 hours, which corresponds to the expiration date after opening, according to the manufacturer recommendations.

\subsection{Reagents}

The chemical reagents used were L-ascorbic acid, 2.6 dichlorophenolindophenol, oxalic acid, and sodium hydroxide (Merck - Darmstadt, Germany).

\subsection{Commercial cashew apple juices analyses}

In order to evaluate the accuracy and precision of the titration method for the ascorbic acid determination (with 2.6 dichlorophenol-indophenol) in cashew apple juices, known amounts of AA were added to one sample of each group of commercial cashew apple juice (CJ and RDJ), selected randomly, and the recovery was tested using the titration method. The experiments were performed in two independent trials and the analyses were conducted in triplicate.

The AA content of commercial cashew apple juices was determined, in triplicate, by the titrimetric method with 2.6 dichlorophenol-indophenol at 0, 2, 4, 6, 24, 30, and 48 hours of storage at $4^{\circ} \mathrm{C}$ in opened bottles. The content of Total Soluble Solids (TSS), expressed in ${ }^{\circ}$ Brix, was obtained by a refractometer (Eppendorf 2763 Bad-Thermostat Modell, Hamburg, Germany), the $\mathrm{pH}$ by a $\mathrm{pH}$ meter supplied with a combined electrode (Micronal B474, São Paulo, Brazil), and the Total Titratable Acidity (TTA) by titration with sodium hydroxide $0.1 \mathrm{~N}$ and expressed as g of citric acid/100 mL. All analyses were performed accor- ding to AOAC (1984). The TSS and TTA contents and the $\mathrm{pH}$ were determined at 0 and 48 hours of storage.

\subsection{Statistical analyses}

Data were subjected to analysis of variance (ANOVA) and the linear regression of the data was carried out using the statistical software Microsoft Excel 97 (Microsoft Corporation, Redmond, USA). The Tukey test was used to obtain paired comparisons among sample means. The level of significance was set at $\mathrm{p} \leq 0.05$ (LOPES, 2001).

\section{Results and discussion}

The data of correlation between added AA and measured concentration in CJ and RDJ, determined by the titration method (Figure 1), showed satisfactory reproducibility and recovery. These results provided strong evidence that the titration method is accurate and reliable for the routine determination of AA in commercial cashew apple juices. Lavinas et al. (2003) found the same results in the analysis of in natura cashew apple juice.

The AA average initial content, reduction rate per hour, and percent loss of RDJ and CJ are shown in Table 1. AA contents of the juice samples showed great variability and were statistically different, except for samples 9 and 10.

The initial content of AA ranged from 37.3 to $46.3 \mathrm{mg} .100 \mathrm{~mL}^{-1}$ with an average of $42.2 \mathrm{mg} .100 \mathrm{~mL}^{-1}$ in the RDJ group. Assunção and Mercadante (2003), determining the AA content of commercial cashew apple juices, obtained an average content of $33.2 \mathrm{mg} .100 \mathrm{~mL}^{-1}$ in RDJ. Valente-Mesquita et al. (2002), evaluating seven brands of commercial ready-to-drink orange juices, reported AA content ranging from 28.1 to $53.2 \mathrm{mg} .100 \mathrm{~mL}^{-1}$.

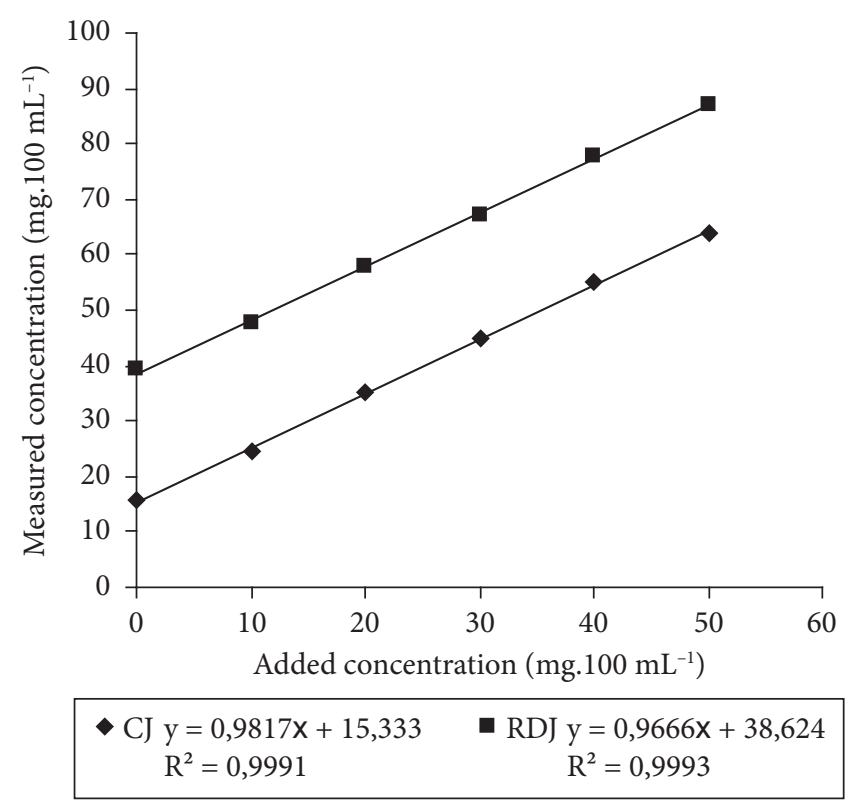

Figure 1. Correlation of added ascorbic acid vs. measured concentration in Concentrated Juice (CJ) and Ready-to-Drink Juice (RDJ) determined by the titration method. 
Table 1. Ascorbic Acid (AA) average initial content, reduction rate and percent loss of commercial cashew apple juices.

\begin{tabular}{cccc}
\hline $\begin{array}{c}\text { Commer- } \\
\text { cial cashew } \\
\text { apple juices }\end{array}$ & $\begin{array}{c}\text { AA average } \\
\text { initial content } \\
(\mathrm{mg} / 100 \mathrm{~mL})^{1}\end{array}$ & $\begin{array}{c}\text { AA reduction rate } \\
(\mathrm{mg} / 100 \mathrm{~mL} / \mathrm{h})^{2}\end{array}$ & $\begin{array}{c}\text { AA percent } \\
\text { Loss }^{2,3}\end{array}$ \\
\hline \multicolumn{4}{c}{ Ready-to-drink juices } \\
1 & $43.1 \pm 0.68^{\mathrm{a}}$ & 0.04 & 6.4 \\
2 & $37.3 \pm 0.68^{\mathrm{b}}$ & 0.00 & 0.0 \\
3 & $46.3 \pm 0.68^{\mathrm{C}}$ & 0.04 & 2.1 \\
& \multicolumn{2}{c}{ Concentrated juices } \\
4 & $97.7 \pm 0.0^{\mathrm{A}}$ & 0.14 & \\
5 & $152.0 \pm 0.68^{\mathrm{B}}$ & 0.14 & 8.8 \\
6 & $147.0 \pm 0.0^{\mathrm{C}}$ & 0.02 & 0.4 \\
7 & $143.0 \pm 0.68^{\mathrm{D}}$ & 0.00 & 0.5 \\
8 & $75.7 \pm 0.68^{\mathrm{E}}$ & 0.00 & 0.0 \\
9 & $114.0 \pm 0.68^{\mathrm{F}}$ & 0.00 & 0.0 \\
10 & $114.0 \pm 0.68^{\mathrm{F}}$ & 0.01 & 0.0 \\
11 & $139.0 \pm 0.68^{\mathrm{G}}$ & 0.01 & 0.7 \\
\hline
\end{tabular}

${ }^{1}$ Means with same lowercase letters for ready-to-drink juices and capital letters for concentrated juices are not significantly different at $5 \%$ probability level. The values are expressed as an average \pm standard deviation $(n=9) ;{ }^{2}$ In juice stored under refrigeration for 48 hours; and ${ }^{3}$ Calculated by the difference between final and initial content

According to some authors (AKINWALE, 2000; CAVALCANTI, 1998; INYANG; ABAH, 1997) cashew apple juice has higher AA content than orange juice. However, it is worth mentioning that the first one has to be diluted before drinking.

The AA content in the CJ group ranged from 75.7 to $152.0 \mathrm{mg} .100 \mathrm{~mL}^{-1}$ with an average of $123.0 \mathrm{mg} .100 \mathrm{~mL}^{-1}$. Previous studies carried out by this same research group (LAVINAS et al., 2003) obtained AA initial content of $147.3 \mathrm{mg} .100 \mathrm{~mL}^{-1}$ in fresh cashew apple juice. The AA content in CJ was up to $48.6 \%$, which is lower than in fresh juice. It is important to consider that the available amount of AA in industrialized foods can be significantly affected due to processing. A probable AA addition to the product should also be considered.

Figure 2 shows AA content variation of ready-to-drink (Figure 2a) and concentrated (Figure 2b) commercial cashew apple juices as a function of storage time under refrigeration $\left(4^{\circ} \mathrm{C}\right)$.

Some CJ presented higher reduction rate than RDJ. The highest percent losses were 6.4 and $8.9 \%$ for RDJ and CJ, respectively. These losses should be considered in diet planning. There are few data on cashew apple juice stability, but some authors reported the stability of vitamin C in industrialized and fresh juices of other fruits. Kabasakalis et al. (2000), studying long-life commercial fruit juices in different concentrations (orange $100 \%$, grapefruit $100 \%$, lemon $17 \%$, cocktail A $100 \%$ and cocktail B 50\%), found higher AA losses in diluted lemon juice than in more concentrated juices. These authors related AA percent loss of 5.7 and $0.6 \%$ to commercial and fresh orange juices stored for 3 days under refrigeration, respectively. Silva et al. (2005) did not find variation in AA values of commercial orange juices under the same storage conditions. Lavinas et al. (2003) reported an average percent loss of $26 \%$ for several commercial lemon juices stored at $4{ }^{\circ} \mathrm{C}$ for 2 days.

After AA analysis in CJ, the AA content in the product diluted according to the manufacturer recommendation (1 part
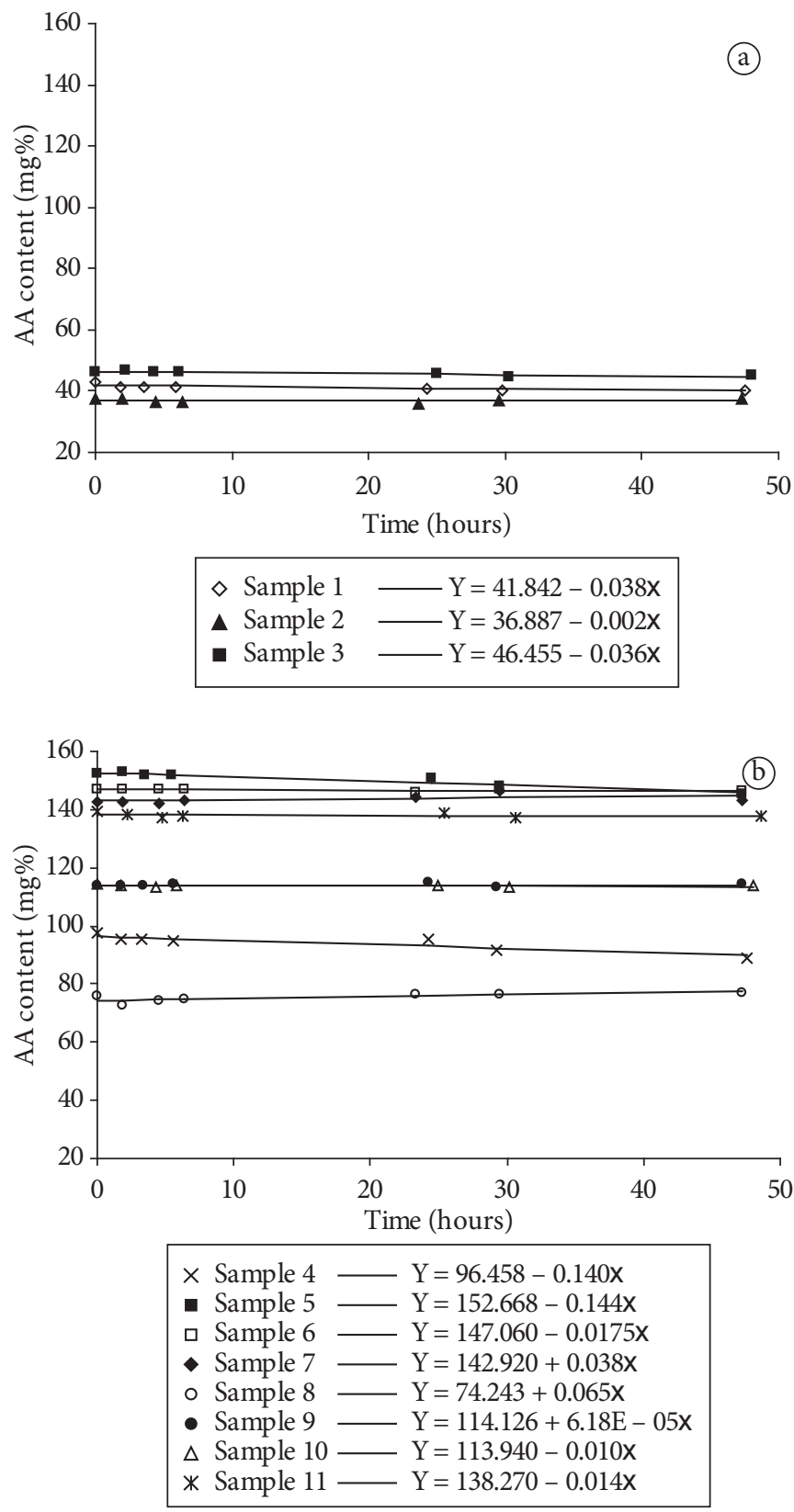

Figure 2. a) AA content variation of ready-to-drink; and b) concentrated commercial cashew apple juices stored under refrigeration for 48 hours. Symbols represent experimental data and the lines, the linear models.

juice: 9 parts water) was calculated. Table 2 shows AA content in $100 \mathrm{~mL}$ of ready-to-drink and concentrated juice after dilution, the AA content described on the label, and necessary volume to achieve Dietary Reference Intakes (DRI, 2001).

Only five samples $(1,3,4,7$, and 11) had AA content displayed on the labels and there was a great difference among them. The content mentioned on the sample labels 1,4 , and 11 were, respectively, $25.3,1078.8$, and $471.4 \%$ higher than those obtained in the analyses of this study. The AA content described on labels of brands 3 and 7 were, respectively, 19.0 and $30.1 \%$ lower than the ones found in this study. 
Higher contents of AA were observed in the RDJ group, but considering the juice the single source of this vitamin, the necessary volume in order to supply the nutritional requirements is lower than that in CJ after dilution.

A portion of $200 \mathrm{~mL}$ of RDJ and diluted CJ contributes, on average, respectively, with $93.9 \%$ and $27.3 \%$ of DRI for men and $112.6 \%$ and $32.8 \%$ for women (Table 2 ). Thus, the necessary volume to achieve DRI ranged from 194 to $1.190 \mathrm{~mL}$ for men and from 162 to $992 \mathrm{~mL}$ for women.

Our results were compared to some chemical composition tables (FRANCO, 1999; IBGE, 1981; PINHEIRO, 2002). Only one of them (FRANCO, 1999) mentioned AA content in commercial bottled cashew apple juices (48.5 mg.100 mL $\mathrm{mL}^{-1}$ ), but it did not specify what kind of juice (RDJ or CJ), neither its dilution. In the others, the data found were only about commercial fruit juices and commercial fruit beverages that did not mention the kind of fruit (IBGE, 1981), or commercial cashew apple be- verages that did not mention dilution (PINHEIRO et al., 2002), which makes it impossible to establish any comparison.

Table 3 shows the physicochemical properties of the analyzed cashew apple juices. Attributes of juice quality as the AA content, TSS, and TTA are determinant factors to fulfill market requirements.

Acidity is an important parameter in food conservation. In general, the decomposition process, by hydrolysis, oxidation, or fermentation, modifies the hydrogen ion concentration, and consequently food acidity (INSTITUTO ADOLFO LUTZ, 1985). RDJ initial acidity ranged from 0.2 to $0.4 \mathrm{~g} .100 \mathrm{~mL}^{-1}$, with an average of $0.3 \mathrm{~g} .100 \mathrm{~mL}^{-1}$ while $\mathrm{CJ}$ acidity ranged from 0.4 to $1 \mathrm{~g} .100 \mathrm{~mL}^{-1}$ with an average of $0.7 \mathrm{~g} .100 \mathrm{~mL}^{-1}$. According to Asenjo (1959), juice acidity ranges proportionality to AA content. In the present study, samples 3 and 5 showed the highest AA values in the RDJ and CJ groups, respectively (Table 2). They also presented the highest TTA values in each group (Table 3 ). Oliveira et al. (1999), studying cashew apple, acerola (Malpighia

Table 2. Initial content of Ascorbic Acid (AA) analyzed and described on the label and the necessary volume of commercial cashew apple juices to achieve DRI.

\begin{tabular}{|c|c|c|c|c|}
\hline \multirow[t]{2}{*}{$\begin{array}{l}\text { Commercial cashew } \\
\text { apple juices }\end{array}$} & \multirow{2}{*}{$\begin{array}{c}\text { AA content } \\
\text { analyzed } \\
\left(\mathrm{mg} .100 \mathrm{~mL}^{-1}\right)\end{array}$} & \multirow[t]{2}{*}{$\begin{array}{l}\text { AA content described on } \\
\text { label }\left(\mathrm{mg} .100 \mathrm{~mL}^{-1}\right)\end{array}$} & \multicolumn{2}{|c|}{$\begin{array}{l}\mathrm{DRI}^{*} \% \text { supplied by } \\
200 \mathrm{~mL} \text { of juice }\end{array}$} \\
\hline & & & Women & Men \\
\hline \multicolumn{5}{|c|}{ Ready-to-drink juices } \\
\hline 1 & 43.1 & 54 & 114.9 & 95.8 \\
\hline 2 & 37.3 & - & 99.5 & 82.9 \\
\hline 3 & 46.3 & 37.5 & 123.5 & 102.9 \\
\hline \multicolumn{5}{|c|}{ Concentrated juices (after dilution) } \\
\hline 4 & 9.77 & 115.5 & 26.1 & 21.7 \\
\hline 5 & 15.2 & - & 40.5 & 33.8 \\
\hline 6 & 14.7 & - & 39.2 & 32.7 \\
\hline 7 & 14.3 & 10.0 & 38.1 & 31.8 \\
\hline 8 & 7.56 & - & 20.2 & 16.7 \\
\hline 9 & 11.4 & - & 30.4 & 25.3 \\
\hline 10 & 11.5 & - & 30.7 & 25.5 \\
\hline 11 & 14.0 & 80.0 & 37.3 & 31.1 \\
\hline
\end{tabular}

${ }^{*} \mathrm{DRI}^{9}$ for women $(75 \mathrm{mg} /$ day) and men $(90 \mathrm{mg} /$ day $)$.

Table 3. Total Soluble Solids (TSS), Total Titratable Acidity (TTA), and pH values of industrialized cashew apple juices as a function of storage time under refrigeration.

\begin{tabular}{|c|c|c|c|c|c|c|}
\hline \multirow{2}{*}{$\begin{array}{c}\text { Commercial cashew } \\
\text { apple juices }\end{array}$} & \multicolumn{3}{|c|}{$\mathrm{T}_{0}$ (Initial time) } & \multicolumn{3}{|c|}{$\mathrm{T}_{48 \text { hours }}$ (Final time) } \\
\hline & TSS ( ${ }^{\circ}$ Brix $)$ & TTA $^{*}$ & $\mathrm{pH}$ & TSS $\left({ }^{\circ}\right.$ Brix & TTA $^{\star}$ & $\mathrm{pH}$ \\
\hline 1 & 12.5 & $0.2 \pm 0.02$ & 3.7 & 12.5 & $0.2 \pm 0.01$ & 3.6 \\
\hline 2 & 12.5 & $0.2 \pm 0.00$ & 3.7 & 12.5 & $0.2 \pm 0.02$ & 3.7 \\
\hline 3 & 11.5 & $0.4 \pm 0.00$ & 3.1 & 11.0 & $0.4 \pm 0.00$ & 3.2 \\
\hline 4 & 9.0 & $0.4 \pm 0.02$ & 4.1 & 9.0 & $0.4 \pm 0.01$ & 4.0 \\
\hline 5 & 9.0 & $1.0 \pm 0.05$ & 3.7 & 9.0 & $0.9 \pm 0.01$ & 3.7 \\
\hline 6 & 10.0 & $0.6 \pm 0.03$ & 3.8 & 10.0 & $0.6 \pm 0.00$ & 3.8 \\
\hline 7 & 11.0 & $1.0 \pm 0.02$ & 3.4 & 11.5 & $1.0 \pm 0.00$ & 3.4 \\
\hline 8 & 10.5 & $0.7 \pm 0.02$ & 3.2 & 10.5 & $0.7 \pm 0.02$ & 3.2 \\
\hline 9 & 10.5 & $0.8 \pm 0.03$ & 3.6 & 10.5 & $0.8 \pm 0.02$ & 3.8 \\
\hline 10 & 10.5 & $0.8 \pm 0.00$ & 3.5 & 10.0 & $0.8 \pm 0.00$ & 3.5 \\
\hline 11 & 10.5 & $0.6 \pm 0.02$ & 3.8 & 10.0 & $0.6 \pm 0.00$ & 3.8 \\
\hline
\end{tabular}

${ }^{\star}$ The values are expressed as an average \pm standard deviation $(n=9)$. 
emarginata), and cajá (yellow mombin) frozen pulps, reported the same relationship between AA contents and acidity. The $\mathrm{pH}$ values and TSS content of the samples remained constant during the analysis. Sample 4 presented the highest $\mathrm{pH}$ value and percent loss of AA. These results are in accordance with Belitz and Grosch (1997), who reported the susceptibility of the AA with the $\mathrm{pH}$ increase. The data of TSS for CJ were lower than $\mathrm{RDJ}$ probably due to the sugar addition to the latter group.

The results obtained were compared to the Brazilian legislation (BRASIL, 2003), which establishes quality and identity patterns to tropical juices. All physicochemical parameters analyzed were in accordance with the legislation.

\section{Conclusions}

There was a large variation in the AA content in the samples analyzed while the AA stability varied only in some of them. Concentrated juices, diluted according to manufacturer recommendation, showed lower contents of AA than readyto-drink juices. Nevertheless, the most consumed juice is the concentrated one due to its variety and low prices.

The TTA, TSS, and $\mathrm{pH}$ remained stable in both ready-todrink and concentrated commercial cashew apple juices which were stored for 48 hours under refrigeration.

These results point to the importance of considering AA losses in commercial cashew apple juices which occurs after opening but before the expiration date expires.

\section{Acknowledgements}

The authors are grateful for the financial support provided by the foundation FAPERJ (Fundação Carlos Chagas Filho de Amparo à Pesquisa do Rio de Janeiro).

\section{References}

AKINWALE, T. O. Cashew apple juice: its use in fortifying the nutritional quality of some tropical fruits. European Food Research and Technology, v. 211, n. 3, p. 205-207, 2000.

AOAC - Association of Official Analytical Chemists. Official Methods of Analysis. 14 ed. Washington DC, 1984.

ASENJO, C. F. La ciência moderna: aspectos químicos para nutritivos de la acerola (Malpighia punicifolia, L.) Ciência-Revista Hispanoamericana de Ciências puras y aplicadas, v. 19, n. 6/7, p. 109-119, 1959.

ASSUNÇÃO, R. B.; MERCADANTE, A. Z. Carotenoids and ascorbic acid composition from commercial products of cashew apple (Anacardium occidentale L.). Journal of Food Composition and Analysis, v. 16, n. 6, p. 647-657, 2003.

BELITZ, H. D.; GROSCH, W. Química de los Alimentos. 2 ed. Zaragoza, Espana: Editorial Acribia, 1997.

BRASIL. Instrução Normativa n. 12, de 04 de Setembro de 2003. Padrões de identidade e qualidade dos sucos tropicais de abacaxi, acerola, cajá, caju, goiaba, mamão, manga, mangaba, maracujá e pitanga. Diário Oficial da República Federativa do Brasil, Brasília, DF, 13 set. 2003.

CAMPOS, D. C. P. et al. Cashew apple juice stabilization by microfiltration. Desalination, v. 148, n. 1-3, p. 61-65, 2002.

CAVALCANTI, J. J. V. 1998. Anacardium occidentale: caju. São Paulo: Conselho Nacional da Reserva da Biosfera, da Mata Atlântica.
Disponível em: http://www.unicamp.br/nipe/ rbma/caju.htm. Acesso em: 08 January 2004.

DRI - Dietary Reference Intakes: Applications in dietary assessment. Washington: National Academy Press, 2001. p. 71-72. Disponível em: www.nap.edu. Acesso em: 24 December 2004.

EUROPEAN PARLIAMENT AND COUNCIL DIRECTIVE No 95/2/EC of 20 February 1995 on food additives other than colours and sweeteners. Disponível em: http://europa.eu.int/eur-lex/en/consleg/ main/1995/ en_1995L0002_index.html. Acesso em: 25 October 2005.

FALVELA, C. V. Frutas cítricas. Nutrição Brasil, v. 3, n. 2, p. 106-114, 2004.

FDA - Food and Drug Administration. Sulfiting agents: affirmation of GRAS status. Fed. Reg. 53: 51065-51084, 1988.

FRANCO, G. Tabela de Composição Química dos Alimentos. 9 ed. São Paulo: Editora Atheneu, 1999.

INSTITUTO ADOLFO LUTZ. Normas Analíticas: Métodos Químicos e Físicos para Análise de Alimentos. 3 ed. São Paulo: Instituto Adolfo Lutz, 1985.

IBGE. Tabela de Composição de Alimentos. 2a ed. Rio de Janeiro: Instituto Brasileiro de Geografia e Estatística, 1981.

INYANG, U. E.; ABAH, U. J. Chemical composition and organoleptic evaluation of juice from steamed cashew apple blended with orange juice. Plant Foods for Human Nutrition, v. 50, n. 4, p. 295-300, 1997.

KABASAKALIS, V.; SIOPIDOU, D.; MOSHATOU, E. Ascorbic acid content of commercial fruit juices and its rate of loss upon storage. Food Chemistry, v. 70, n. 3, p. 325-328, 2000.

LAVINAS, F. C. et al. Variação no teor de ácido ascórbico em sucos de limão industrializados. In: Simpósio Latino Americano de Ciência de Alimentos, 5, 2003, Campinas. Anais... Campinas, 2003. (CD-ROM).

LOPES, P. A. Probabilidades e estatística. Rio de Janeiro: Reichmann \& Affonso Editores, 2001.

MAIA, G. A.; MONTEIRO, J. C. S.; GUIMARÃES, A. C. L. Estudo da estabilidade fisico-química e química do suco de caju com alto teor de polpa. Ciência e Tecnologia de Alimentos, v. 21, n. 1, p. 43-46, 2001.

MARÍN, F. R. et al. Changes in nutraceutical composition of lemon juices according to different industrial extraction systems. Food Chemistry, v. 78, n. 3, p. 319-324, 2002.

OLIVEIRA, M. E. B. et al. Avaliação de parâmetros de qualidade físicoquímicos de polpas congeladas de acerola, cajá e caju. Ciência e Tecnologia de Alimentos, v. 19, n. 3, p. 326-332, 1999.

PINHEIRO, A. B. V. et al. Tabela para Avaliação de Consumo Alimentar em Medidas Caseiras. 4 ed. São Paulo: Editora Atheneu, 2002.

REDDY, M. B.; LOVE, M. The impact of food processing on the nutritional quality of vitamins and minerals. Advances in Experimental Medicine and Biology, v. 459, n. 1, p. 99-106, 1999.

SILVA, P. T. et al. Sucos de laranja industrializados e preparados sólidos para refrescos: estabilidade química e físico-química. Ciência e Tecnologia de Alimentos, v. 25, n. 3, p. 401-622, 2005.

SOARES, L. M. V. et al. Composição mineral de sucos concentrados de frutas brasileiras. Ciência e Tecnologia de Alimentos, v. 24, n. 2, p. 202-206, 2004.

VALENTE-MESQUITA, V. L. et al. Teor de vitamina C em suco de cultivares de laranja (Citrus sinensis) e em diferentes sucos industrializados. Nutrição Brasil, v. 1, n. 1, p. 34-39, 2002.

VALIM, M. F.; ROUSEFF, R. L.; LIN, J. Gas chromatographicolfatometric characterization of aroma compounds in two types of cashew apple nectar. Journal of Agricultural and Food Chemistry, v. 51, n. 4 , p. 1010-1015, 2003. 